\title{
A DESCRIPTIVE-COMPARATIVE STUDY OF PRE- AND POST-OPERATIVE CONTINUOUS PERITONEAL LAVAGE WITH ANTIBIOTIC-RINGER'S LACTATE SOLUTION IN PERFORATION PERITONITIS
}

\author{
Mahesh Chandra Pandey ${ }^{1}$, M. S. Zutshi', H. S. Rawat ${ }^{3}$, H. S. Nagar ${ }^{4}$, R. K. Srivastava ${ }^{5}$ \\ ${ }_{1}^{1}$ Assistant Professor, Department of Surgery, TSM Medical College, Lucknow. \\ ${ }^{2}$ Assistant Professor, Department of Surgery, TSM Medical College, Lucknow. \\ 3 Professor and HOD, Department of Surgery, TSM Medical College, Lucknow. \\ 4 Professor, Department of Surgery, TSM Medical College, Lucknow. \\ 5 Professor, Department of Surgery, TSM Medical College, Lucknow.
}

\section{ABSTRACT}

\section{BACKGROUND}

Peritonitis is defined as an inflammatory process of the peritoneum caused by any irritant or agent. Peritoneal lavage plays an important role in the treatment of peritonitis. Different studies showed the result of different solutions such as normal saline, antibiotics, and Betadine as peritoneal lavage.

Aim of this study was to find out the role of pre- and post-operative peritoneal lavage with antibiotic-Ringer's lactate as an alternative to other existing fluids.

\section{MATERIALS AND METHODS}

This descriptive-comparative study evaluates the role of pre and post-operative continuous peritoneal lavages with antibioticRinger's lactate in diffuse peritonitis. Total 100 diffuse peritonitis patients were compared internally by subclassifying them in to three groups: one control group, study group 1 and study group 2. Ringer's lactate was the solution of lavage in study group 1 and Ringer's lactate with antibiotics (ceftriaxone+gentamicin+metronidazole) was used in study group 2.

\section{RESULTS}

In this descriptive-comparative study, the most common cause of the perforation was enteric perforation followed by peptic perforation. Mortality rate was 30\% in control group and 10\% in study group 1 and $5 \%$ in study group 2 . Duration of post-operative ileus was 5.6 days in control group and 5.5 days in study group 1 and 3.6 in study group 2. Mean hospital stay period in cured patients was 21.28 in control group, 20.4 in study group 1 and 14.89 in study group 2.

\section{CONCLUSION}

From the results of this study, it is evident that peritoneal lavage using antibiotic-Ringer's lactate solution is significantly effective in reducing both morbidity and mortality in patients having severe diffuse peritonitis. The outcome of the treatment depends upon decreasing the toxic load in the peritoneum for which various methods have been tried. This study has shown that Ringer's lactate with antibiotics gives better outcome in terms of morbidity and mortality in perforation peritonitis.

\section{KEYWORDS}

Ringer's Lactate, Perforation Peritonitis, Peritoneal Lavage.

HOW TO CITE THIS ARTICLE: Pandey MC, Zutshi MS, Rawat HS, et al. A descriptive-comparative study of pre- and post-operative continuous peritoneal lavage with antibiotic-Ringer's lactate in perforation peritonitis. J. Evolution Med. Dent. Sci. 2017;6(91): 64386442, DOI: $10.14260 / \mathrm{jemds} / 2017 / 1400$

\section{BACKGROUND}

Peritonitis is defined as inflammation of the serosal membrane that lines the abdominal cavity and the organ contained therein. The peritoneum, which is an otherwise sterile environment, reacts to various pathological stimuli with a fairly uniform inflammatory response. Depending on the underlying pathology, the resultant peritonitis may be infectious or sterile (i.e. chemical or mechanical). The most common aetiology of peritonitis is infection resulting in perforation of rupture of viscera. 1,2

'Financial or Other Competing Interest': None.

Submission 14-06-2017, Peer Review 08-11-2017,

Acceptance 15-11-2017, Published 27-11-2017.

Corresponding Author:

Dr. Mahesh Chandra Pandey,

Assistant Professor

Department of Surgery,

TSM Medical College and Hospital,

Lucknow.

E-mail:mp211177@gmail.com

DOI: $10.14260 /$ jemds $/ 2017 / 1400$

\section{(c) (i) $(9)$}

Management of peritonitis remains a major clinical problem. High mortality and morbidity in the patients suffering from generalised peritonitis is known for years.

Resultant septicaemia, circulatory instability, renal and pulmonary insufficiency leads to death in $30-60 \%$ of patients (Stephan \& Loewenthal).

These dreadful manifestations of peritonitis are most commonly due to spillage of gastrointestinal contents into the peritoneal cavity which can be prevented by immediate removal and neutralisation of contaminants. With the rapid advances in medicine and method of surgical treatment, the morbidity from this dreadful disease has been appreciably reduced.

The instillation of crystalloids solution into peritoneal cavity during the laparotomy is a routine practice for many Surgeons. ${ }^{3}$ Intra-operative lavage was first introduced by Nolan (1893) and Price (1904). In 1957, Burnett re-introduced the intra-operative lavage of peritoneal cavity and suggested that favourable results were due to mechanical removal of the toxins from the tremendous absorptive area and washing away of bacteria which have to be overcome by body defences. 
Several other studies also support the idea that intraoperative irrigation with normal saline in the absence of other antimicrobial substance have no beneficial effect. 4,5 Therefore, the study of pre and post-operative continuous peritoneal lavage with antibiotic solution deserves further clinical trial to establish its role as an adjunctive lifesaving measure in diffuse peritonitis. It has been advocated that morbidity and mortality associated with peritonitis can further be reduced if irrigation of peritoneal cavity is continued in pre and post-operative phase using antibiotic thereby removing the debris, bacteria and other noxious agents and directly attacking bacteria which is not possible to achieve by systemic administration safely. The procedure has been utilised by Caridis (1969); McKenna et al (1970); Stephan and Loewenthal.

\section{Objectives-}

1. To study the effect of pre- and post-operative continuous peritoneal lavage using antibiotic-Ringer's lactate solution on morbidity and mortality in case of severe diffuse peritonitis.

2. To study the effectiveness of pre and post-operative lavage in reducing toxaemia and hence helping in patient recovery.

3. To study the various causes associated with severe diffuse peritonitis.

\section{MATERIALS AND METHODS}

This descriptive-comparative study was carried out in Department of Surgery at different hospitals.

\section{Design}

Descriptive-comparative study.

\section{Study Period}

Five years.

\section{Sampling}

A sample size of 100 patients (over the period of 5 years) was considered in different hospitals. In all peritonitis patients, we have compared internally by subdividing the group into 3 .

\section{Sampling Procedure}

For this comparative study, the details of all the 100 patients diagnosed with perforation peritonitis were collected from different hospitals over the period of 5 years. Those who underwent these two lavage procedures during the management were compared by dividing into 3 groups.

\section{Study Population}

In this comparative study, minimum age of the patient was 11 years and maximum was 75 years. In this comparative study, out of 100 patients, 25 were female while 75 were male. Out of 100 patients, 80 were from rural area and only 20 were from urban region. The incidence of diffuse perforation peritonitis is distributed in all age groups, both male and female. In this comparative study, IBM-compatible statistical package version 20.0 was used. In this study, $p$ value at $<0.05$ was consider significant and at $>0.05$ was considered not significant while at $<0.001$ was considered highly sensitive. Chi square test was used in this study for $\mathrm{p}$ value.

\section{Group 1 (Control Group n - 30)}

The patients were treated by conventional method. In these 30 patients of perforation peritonitis, laparotomy was done and intra-operative peritoneal lavage was carried out using Ringer's lactate solution to remove debris.

\section{Group 2 (Study Group 1 n-30)}

These patients were treated as in the control group with the addition of pre and post-operative continuous peritoneal lavage with sterile Ringer's lactate solution for 48 to 96 hours till the returning fluid appears clear macroscopically.

\section{Group 3 (Study Group 2 n-40)}

These patients were treated as in the control group with the addition of pre and post-operative continuous peritoneal lavage with Ringer's lactate + Ceftriaxone $1 \mathrm{~g} / \mathrm{L}+$ Gentamycin $80 \mathrm{mg} / \mathrm{L}+$ Metronidazole $100 \mathrm{~mL} / \mathrm{L}$ for 48 to 96 hours till the returning fluids appeared clear macroscopically.

The minimum age in control group was 11 and maximum was 75 years. In the first study group, minimum and maximum age was 22 and 65 respectively. In the second study group, minimum and maximum age was 14 and 55 years respectively. The mean age in control, study group 1 and study group 2 was $36.6,39.2$ and 31.33 years respectively.

In all the Groups, observations have been made with the following format

1. Age, sex, and geographical distribution.

2. Duration of illness/perforation.

3. Aetiology of perforation.

4. Intra and post-operative lavage.

5. Bacteriological study - culture/sensitivity.

\begin{tabular}{|c|c|c|c|}
\hline Sex & Control & Study Group 1 & Study Group 2 \\
\hline Male & 24 & 21 & 30 \\
\hline Female & 6 & 9 & 10 \\
\hline Total & $\mathbf{3 0}$ & $\mathbf{3 0}$ & $\mathbf{4 0}$ \\
\hline \multicolumn{3}{|c|}{ Table. 1 Sex Ratio } \\
\hline
\end{tabular}

\section{Postoperative Course}

- Duration of post-operative fever.

- Duration of post-operative ileus.

- Duration of azotaemia.

- Post-operative complications.

- Respiratory complications.

- Intraperitoneal abscess (subphrenic/pelvic).

- Faecal fistula.

- Wound infection.

- Wound dehiscence (partial/complete).

- Stay of patient in hospital.

- Mortality.

\section{RESULTS}

In this study, total 100 patients were included having peritonitis due to enteric, duodenal and appendicular perforation, post MTP uterine and bowel perforation. Most of the cases were due to enteric perforation and came from rural areas. In our study, the maximum incidence of peritonitis was found in $3^{\text {rd }}$ and $4^{\text {th }}$ decade in majority of the patients. 


\begin{tabular}{|c|c|c|c|c|c|c|}
\hline \multirow[t]{2}{*}{$\begin{array}{l}\text { Cause of } \\
\text { Peritonitis }\end{array}$} & \multicolumn{2}{|c|}{$\begin{array}{c}\text { Control } \\
\text { Group } \\
\text { (Group-I) }\end{array}$} & \multicolumn{2}{|c|}{$\begin{array}{c}\text { Study } \\
\text { Group-1 } \\
\text { (Group II) }\end{array}$} & \multicolumn{2}{|c|}{$\begin{array}{c}\text { Study } \\
\text { Group-II } \\
\text { (Group-III) }\end{array}$} \\
\hline & No. & $\%$ & No. & $\%$ & No. & $\%$ \\
\hline $\begin{array}{c}\text { Enteric } \\
\text { perforation }\end{array}$ & 21 & 70 & 24 & 80 & 36 & 90 \\
\hline $\begin{array}{l}\text { Peptic ulcer } \\
\text { perforation }\end{array}$ & 9 & 30 & 6 & 20 & 2 & 5 \\
\hline $\begin{array}{l}\text { Appendicular } \\
\text { perforation }\end{array}$ & - & & - & _ & 2 & 5 \\
\hline $\begin{array}{c}\text { Uterine } \\
\text { perforation }\end{array}$ & - & & - & & - & \\
\hline Total & 30 & & 30 & & 40 & \\
\hline$T c$ & S & & use & & & \\
\hline
\end{tabular}

Incidence of post-operative complication decreased in study group 2 as compared to study group 1 and control group because of continuous peritoneal irrigation by antibioticRinger's lactate solution. Klebsiella was the most common organism cultured and isolated from the fluid of the peritoneal cavity.

In the control group, leakage was seen from the repair site in 9 cases (30\%), wound infection was seen in 24 cases $(80 \%)$ with partial dehiscence in 3 cases (10\%) and complete dehiscence in 3 cases (10\%). In the study group 1, no leakage was seen and wound infection was seen in 24 cases $(80 \%)$ with partial dehiscence in 21 cases (70\%) and complete dehiscence in 3 cases (10\%). There was no residual abscess in this group. In the study group 2, leakage from duodenal repair site was seen in 2 cases (5\%) and wound infection in 14 cases (35\%) with partial dehiscence in 12 cases $(30 \%)$ and complete dehiscence in 4 cases $(10 \%)$ and there was no residual abscess. Incidence of post-operative complication decreased in study group 2 as compared to study group 1 and control group because of continuous peritoneal irrigation by antibiotic-loaded Ringer's lactate solution.

In our series of cases, the incidence of severe diffuse perforation peritonitis was higher in rural areas. Eighty cases were from rural areas while only 20 cases were from urban areas. In control group, there were 25 cases from rural areas while in study group 1 and 2 the cases were 27 and 28 respectively. The number of cases from urban area was 5 in control group and 3 and 12 in study group 1 and study group 2 respectively.

\begin{tabular}{|c|c|c|}
\hline Group & Rural & Urban \\
\hline Control group (30) & 25 & 5 \\
\hline Study group 1 (30) & 27 & 3 \\
\hline Study group $2(40)$ & 28 & 12 \\
\hline Total (100) & 80 & 20 \\
\hline
\end{tabular}

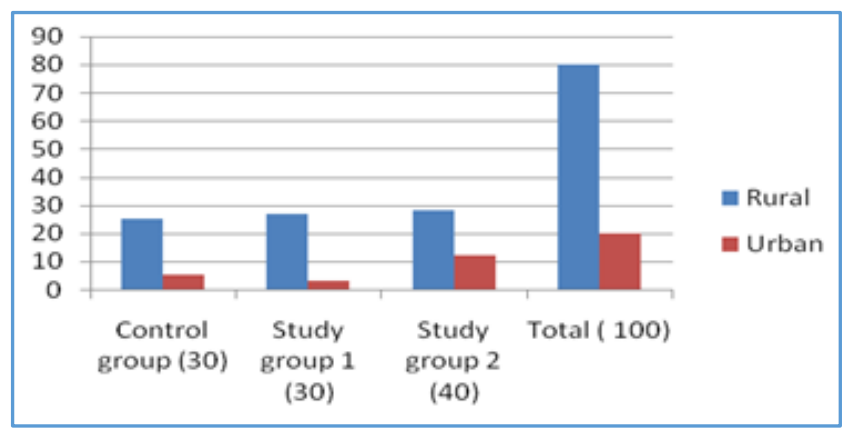

Graph 1. Rural/Urban Distribution

\begin{tabular}{|c|c|c|c|c|c|c|}
\hline \multirow{2}{*}{ Complications } & $\begin{array}{c}\text { Control } \\
\text { Group } \\
\text { (Group-I) }\end{array}$ & \multicolumn{2}{c|}{$\begin{array}{c}\text { Study } \\
\text { Group-1 } \\
\text { (Group II) }\end{array}$} & $\begin{array}{c}\text { Study } \\
\text { Group-2 } \\
\text { (Group-III) }\end{array}$ \\
\cline { 2 - 7 } No. & $\%$ & No. & $\%$ & No. & $\%$ \\
\hline $\begin{array}{c}\text { Wound } \\
\text { infection }\end{array}$ & 24 & 80 & 24 & 80 & 14 & 35 \\
\hline $\begin{array}{c}\text { Wound } \\
\text { dehiscence }\end{array}$ & 3 & 10 & 21 & 70 & 12 & 30 \\
\hline Partial & 3 & 10 & 3 & 10 & 4 & 10 \\
\hline Complete & 6 & 20 & - & - & - & - \\
\hline $\begin{array}{c}\text { Residual } \\
\text { abscesses }\end{array}$ & 9 & 30 & 6 & 20 & - & - \\
\hline Prolonged ileus & 9 & \multicolumn{7}{|c|}{\begin{tabular}{l} 
\% \\
\hline Faecal Fistula
\end{tabular}} & 9 & 30 & - & 20 & 2 & 5 \\
\hline \multicolumn{6}{|c|}{ Table 4. Post-operative Complications } \\
\hline
\end{tabular}

\begin{tabular}{|c|c|c|c|c|c|c|}
\hline \multirow{2}{*}{$\begin{array}{c}\text { Duration } \\
\text { of stay } \\
\text { (Days) }\end{array}$} & $\begin{array}{c}\text { Control Group } \\
\text { (Group-I) }\end{array}$ & $\begin{array}{c}\text { Study Group-1 } \\
\text { (Group II) }\end{array}$ & $\begin{array}{c}\text { Study Group-2 } \\
\text { (Group-III) }\end{array}$ \\
\cline { 2 - 7 } & No. & $\mathbf{\%}$ & No. & $\mathbf{\%}$ & No. & $\%$ \\
\hline $8-15$ & 6 & 25 & 6 & 22.22 & 26 & 68.42 \\
\hline $16-22$ & 15 & 62.5 & 15 & 55.55 & 12 & 21.05 \\
\hline $23-29$ & - & - & & - & & - \\
\hline $30-37$ & - & - & 6 & 22.22 & 6 & 10.52 \\
\hline$>36$ & 3 & 12.5 & & - & & - \\
\hline Total & $\mathbf{2 4}$ & $\mathbf{1 0 0}$ & $\mathbf{2 7}$ & $\mathbf{1 0 0}$ & $\mathbf{4 4}$ & $\mathbf{1 0 0}$ \\
\hline p- value & \multicolumn{7}{|c|}{ (T<=) two tail } & \multicolumn{3}{|c|}{0.419} & \\
\hline \multicolumn{7}{|c|}{ Table 5. Correction of Azotaemia } \\
\hline
\end{tabular}

In Control Group, the average duration of hospital stay was 21.28 days while in study group 1 and study group 2 it was 20.4 and 14.89 respectively. The mean day of appearance of normal blood urea was 4 days in control group while it was 1.33 days and 1.6 days for group 1 and group 2 respectively. Among the control group, average appearance of bowel sound was 5.6 days while it was 5.5 days and 3.6 days among the study group 1 and study group 2 respectively. 
Decreased infection rate, decreased purulent discharge from the drain and early removal of drain in study group 2 caused early appearance of bowel sound and led to oral intake and improvement in morbidity and mortality rate in study group 2 .

Overall mortality was $30 \%$ in control group while it was $10 \%$ in study group 1 and $5 \%$ in study group 2 .

\begin{tabular}{|c|c|c|c|c|c|c|}
\hline $\begin{array}{c}\text { Day Of } \\
\text { Appearance of } \\
\text { Normal B.Urea }\end{array}$ & \multicolumn{2}{|c|}{$\begin{array}{c}\text { Control } \\
\text { Group }\end{array}$} & \multicolumn{2}{c|}{$\begin{array}{c}\text { Study } \\
\text { Group 1 }\end{array}$} & \multicolumn{2}{c|}{$\begin{array}{c}\text { Study } \\
\text { Group 2 }\end{array}$} \\
\hline 1 & 3 & $25 \%$ & 6 & $33.33 \%$ & 10 & $50 \%$ \\
\hline 2 & 3 & $25 \%$ & 9 & $50 \%$ & 6 & $30 \%$ \\
\hline 3 & 3 & $25 \%$ & - & - & 2 & $10 \%$ \\
\hline 4 & - & - & 3 & $16.67 \%$ & 2 & $10 \%$ \\
\hline$>4$ & 3 & $25 \%$ & - & - & - & - \\
\hline Total & 12 & $100 \%$ & 18 & $100 \%$ & 20 & $100 \%$ \\
\hline P-value (t<=) & Two tail- 0.496 & \multicolumn{1}{|l}{} \\
\hline \multicolumn{7}{|c|}{ Table 6. Duration of Hospital Stay } \\
\hline
\end{tabular}

\begin{tabular}{|c|c|c|c|c|c|c|}
\hline $\begin{array}{c}\text { Post-op } \\
\text { Days }\end{array}$ & \multicolumn{2}{|c|}{$\begin{array}{c}\text { Control } \\
\text { Group }\end{array}$} & \multicolumn{2}{c|}{$\begin{array}{c}\text { Study } \\
\text { Group-1 }\end{array}$} & \multicolumn{2}{c|}{$\begin{array}{c}\text { Study } \\
\text { Group-2 }\end{array}$} \\
\hline & No. & $\%$ & No. & $\%$ & No. & $\%$ \\
\hline $\begin{array}{c}\text { Survived \& } \\
\text { cured }\end{array}$ & 21 & 70 & 27 & 90 & 38 & 95 \\
\hline Mortality & 9 & 30 & 3 & 10 & 2 & 5 \\
\hline Total & 30 & 100 & 30 & 100 & 40 & 100 \\
\hline \multicolumn{6}{|c|}{ Table 7. Mortality } \\
\hline
\end{tabular}

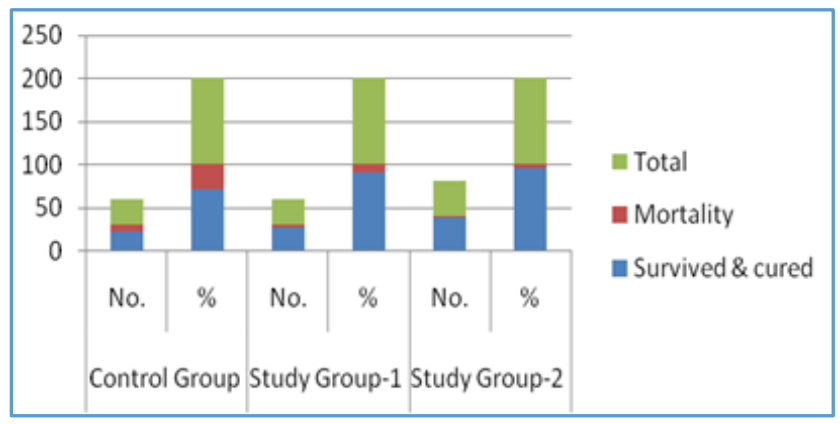

Graph 2. Distribution of Mortality

Postoperative recovery from Azotaemia was found to be quicker in study groups as compared to control group. Mean duration of Azotaemia in post-operative period in control group was 4 days as compared to study groups where it was 1.33 in study group 1 and 1.6 days in study group 2 .

Post-op Fever in Various Groups

\begin{tabular}{|c|c|c|c|c|c|c|}
\hline $\begin{array}{c}\text { Post-op } \\
\text { Days }\end{array}$ & $\begin{array}{c}\text { Control } \\
\text { Group }\end{array}$ & \multicolumn{2}{c|}{$\begin{array}{c}\text { Study } \\
\text { Group-1 }\end{array}$} & \multicolumn{2}{c|}{$\begin{array}{c}\text { Study } \\
\text { Group-2 }\end{array}$} \\
\hline & No. & $\mathbf{\%}$ & No. & $\mathbf{\%}$ & No. & \% \\
\hline 1 & 30 & 100 & 30 & 100 & 38 & 95 \\
\hline 2 & 30 & 100 & 30 & 100 & 22 & 55 \\
\hline 3 & 27 & 90 & 27 & 90 & 12 & 30 \\
\hline 4 & 27 & 90 & 21 & 70 & 10 & 25 \\
\hline 5 & 12 & 40 & 6 & 20 & 6 & 15 \\
\hline 6 & 12 & 40 & 6 & 20 & 2 & 5 \\
\hline \multicolumn{6}{|c|}{ Table 9. Post-op Fever } \\
\hline
\end{tabular}

$\mathrm{P}$ - value $(\mathrm{T}<=)$ two tail 0.419
This study proves (as shown in the chart) postoperative lavage with antibiotic-Ringer's lactate solution significantly reduced the duration of postoperative fever. But there was no significant reduction in duration of postoperative fever by lavage with only Ringer's lactate.

\section{DISCUSSION}

Peritonitis is defined as the inflammation of the thin tissue surrounding the abdominal organ. Perforative peritonitis occurs in the setting of gastrointestinal perforation. ${ }^{5}$ The present day therapy of peritonitis includes elimination of source of contamination, the use of adequate dose of systemic antibiotics and circulatory support. The mainstay of treatment in case of perforation is the surgical closure. Along with this, intra-operative peritoneal lavage plays an important role in the treatment of the peritonitis. ${ }^{6}$ The role of intra-operative peritoneal irrigation and post-operative continuous lavage with or without specific antimicrobial agent and drainage process continue to be variable. Several studies also support the idea that intraperitoneal irrigation with normal saline, in the absence of other microbial substance, has no beneficial effect. ${ }^{7}$ Schien et al $^{8}$ found no significant difference in mortality of patients treated with or without intraperitoneal lavage with chloramphenicol. Rambo ${ }^{9}$ also found no difference in the number of deaths when intraperitoneal irrigation with antibiotic (cephalothin) was used. On contrary, McKenna et $\mathrm{al}^{10}$ and Bhushan et $\mathrm{al}^{11}$ found a significant reduction in mortality in patients treated with antibiotic lavage. Lavage helps to restore the haemostasis in patients of peritonitis by performing an efficient aqueous debridement and restore the normal fluid and electrolyte balance by correcting abnormalities in acid-base balance.

\section{CONCLUSION}

This study was undertaken to study the role of continuous postoperative peritoneal lavage using antibiotic-Ringer's lactate in severe diffuse peritonitis as a useful lifesaving adjunctive treatment. The mean age of patients in control group was 36.6 years while mean age in the study group 1 and 2 was 39.2 years and 31.3 years respectively with male to female ratio $8: 2$ in control group and 7:3 and 15:5 group 1 and group 2 respectively. In all the patients, enteric perforation was most common $82.5 \%$ followed by peptic ulcer perforation $15 \%$ and appendicular perforation $2.5 \%$. Klebsiella was the most common organism among aerobes (65\%) followed by E. coli (35\%). 95\% patients were cured in study group 2 while in study group 1 and control group this rate was 90\%, and $70 \%$ respectively. In post-operative complication, in control group $80 \%$ had wound infection as compared to study group 1 and study group 2 where this figure was $80 \%$ and $35 \%$ respectively.

From results of this study, it is evident that peritoneal lavage using antibiotic-Ringer's lactate solution is significantly effective in reducing both morbidity and mortality in patients having severe diffuse peritonitis. The lavage with only Ringer's lactate is not as good as antibiotic-Ringer's lactate solution and it is more or less equal to control group (conventional therapy) in diffuse peritonitis.

\section{REFERENCES}

[1] Saha SK. Peritoneal lavage with metronidazole. Surg Gynecol Obstet 1985;160(4):335-8. 


\section{Jemds.com}

[2] Whiteside OJH, Tytherleigh MG, Thrush S, et al. Intraoperative peritoneal lavage-who does it and why? Ann R Coll Surg Engl 2005;87(4):255-8.

[3] Burnett WE, Brown GR, Rosemond GP, et al. The treatment of peritonitis using peritoneal lavage. Ann Surg 1957;145(5):657-81.

[4] Lally KP, Nicholas RL. Various intraperitoneal irrigation solutions in treating experimental fecal peritonitis. South Med J 1981;74(7):789-91, 798.

[5] Rakower SR, Keyes J, Miethaner WL. The protective role of intraperitoneal antibiotic irrigation in contaminated penetrating wound of the cecum. Surgery 1976;80(3):405-10.

[6] Schein M, Gecelter G, Freinkel W, et al. Peritoneal lavage in abdominal sepsis. A controlled clinical study. Arch Surg 1990;125(9):1132-5.

\section{Original Research Article}

[7] Myers E, Hurley M, O’Sullivan GC, et al. Laparoscopic peritoneal lavage for generalized peritonitis due to perforated diverticulitis. Br J Surg 2008;95(1):97-101.

[8] Zhao K, Kirman I, Tschepen I, et al. Peritoneal lavage reduces lipopolysaccharide-induced elevation of serum TNF-alpha and IL-6 mortality in mice. Inflammation 1997;21(4):379-90.

[9] Rambo WM. Irrigation of the peritoneal cavity with cephalothin. Am J Surg 1972;123(2):192-5.

[10] McKenna JP, Currie DJ, MacDonald JA, et al. The use of continuous peritoneal lavage in management of diffuse peritonitis. Surg Gynecol Obstet 1970;130(2):254-8.

[11] Bhushan C, Mittal VK, Elhence IP. Continuous postoperative peritoneal lavage in diffuse peritonitis using balanced saline antibiotic solution. Int Surg 1975;60(10):526-8. 